\title{
Dejan Hozjan, Nina Krmac \\ VKLJUČENOST IN OVIRE PRI IZOBRAŽEVANJU ODRASLIH V EVROPSKI UNIJI OB ZAČETKU GOSPODARSKE RECESIJE
}

\section{POVZETEK}

Gospodarska recesija je pomembno zaznamovala življenžje prebivalcev Evropske unije. Od leta 2008, ko se pojavijo prvi znaki recesije, sta se povečali brezposlenost in revščina v večini članic Evropske unije. Številni evropski in nacionalni strateški dokumenti so kot enega ključnih neekonomskih instrumentov izhoda iz recesije omenjali vlaganje v izobraževanje. Prepričanje politikov o pomembni vlogi izobraževanja pri reševanju gospodarske recesije pa odpira vprašanje o dejanskih spremembah na tem področju. $V$ prispevku je na eni strani prikazano razumevanje vloge izobraževanja odraslih pri gospodarskem razvoju v evropskih strateških dokumentih in na drugi strani vključenost odraslih v izobraževanje in ovire pri tem ob začetku gospodarske recesije.

Ključne besede: izobraževanje odraslih, gospodarska recesija, vključevanje v izobraževanje, ovire v izobraževanju, Evropska unija

\section{PARTICIPATION AND OBSTACLES IN ADULT EDUCATION IN THE EUROPEAN UNION AT THE BEGINNING OF THE ECONOMIC RECESSION - ABSTRACT}

The economic recession has exerted an important influence on the lives of the population in the European Union. Since 2008, when initial indications of the recession appeared,unemployment and poverty have increased in most member states of the European Union. Many European and national strategic documents were exposed; one of the key non-economic factors in easing out of a recession is investment in the development of knowledge. Political opinion regarding the important role of knowledge in solving problems of the economic recession raises the question of actual change in this area. In this paper, an understanding of the role of adult education in economic development (as outlined in the European strategic documents) is demonstrated, and in opposition to the same, an analysis of participation (and obstacles) in adult education at the beginning of the economic recession is pursued.

Keywords: adult education, economic recession, participation in education, obstacles in education, European Union

Izr. prof. dr. Dejan Hozjan, Pedagoška fakulteta Univerze na Primorskem, dejan.hozjan@pef.upr.si

Mag. Nina Krmac, Pedagoška fakulteta Univerze na Primorskem,nina.krmac@pef.upr.si 


\section{UVOD}

Gospodarska recesija je pomembno vplivala na zvišanje stopnje brezposelnosti in revščine prebivalstva Evropske unije. V zadnjih šestih letih se je brezposelnost v Evropski uniji povečala za 57,1 odstotka oziroma za 9,6 milijona prebivalcev. Revščina pa se je dvignila za 5,5 odstotka oziroma je zajela 6,4 milijona prebivalcev Evropske unije več kot pred gospodarsko krizo (Europe 2020 indicators, 2014). Skrb zbujajočim podatkom o brezposelnosti in revščini se ne morejo izogniti snovalci mednarodnih in nacionalnih politik, ki s pomočjo različnih strateških dokumentov in finančnih spodbud iščejo ustrezno rešitev za gospodarsko recesijo. Da se kot rešitev za gospodarsko recesijo v ospredje postavljata kakovosten izobraževalni sistem in ustrezna razvitost človeških virov, nas lahko prepriča izjava generalnega sekretarja OECD Joseja Angela Gurria iz leta 2009: »V gospodarski recesiji se pritiski na učinkovitejše delovanje izobraževalnih sistemov krepijo iz dveh smeri. Po eni strani se običajno močno poveča prizadevanje za omejevanje sredstev. Po drugi strani pa postanejo naložbe v človeške vire še pomembnejše, saj bo prav pridobitev ustreznih znanj in veščin nujen prvi pogoj za gospodarsko okrevanje.« (Education at a glance: OECD indicators, 2009, str. 2) Generalni sekretar OECD je torej na začetku gospodarske recesije menil, da bo gospodarsko okrevanje temeljilo na kakovostnem izobraževalnem sistemu in ustrezno razvitih človeških virih.

Ker je izobraževanje odraslih eden ključnih dejavnikov razvoja človeških virov, bomo v prispevku iskali odgovor na vprašanje, kako je opredeljena vloga izobraževanja odraslih pri reševanju gospodarske recesije $\mathrm{v}$ strateških dokumentih Evropske unije in na kakšnih dejanskih temeljih na področju izobraževanja odraslih je Evropska unija vstopila v gospodarsko recesijo. Pri slednjem bo poseben poudarek namenjen prikazu vključevanja odraslih v izobraževanje in oviram, ki jim to najpogosteje preprečujejo.

\section{VLOGA IZOBRAŽEVANIA ODRASLIH PRI GOSPODARSKEM RAZVOJU V TEMELJNIH STRATEŠKIH DOKUMENTIH EVROPSKE UNIJE}

\section{Smernice razvoja izobraževanja odraslih glede na Lizbonsko strategijo}

V želji po razumevanju vloge izobraževanja odraslih pri gospodarskem razvoju na začetku gospodarske recesije v Evropski uniji se je treba ozreti na Lizbonsko strategijo iz leta 2000, ki je bila jedrni strateški dokument Evropske unije v prvem desetletju tega stoletja. Temeljni strateški cilj v Lizbonski strategiji priča o tem, da naj bi pridobivanje znanja (in posledično izobraževanje) imelo ključno vlogo pri gospodarskem razvoju Evropske unije. »Do leta 2010 naj bi postala (Evropska unija, op. av.) najbolj konkurenčno in dinamično gospodarstvo na svetu, temelječe na znanju, zmožno trajnostnega gospodarskega razvoja z več in boljšimi delovnimi mesti ter boljšo socialno kohezijo in spoštovanjem okolja.« (Lisbon European Council, 2000, str. 1) Z Lizbonsko strategijo se torej vzpostavi prepričanje, da lahko le ustrezno znanje popelje Evropsko unijo na položaj svetovnega prvaka na področju gospodarstva, sociale in okoljevarstva. S pomočjo izobraževanja naj bi se torej vzpostavilo na znanju temelječe gospodarstvo, katerega temeljna naloga naj bi bila 
ustvarjanje novih delovnih mest ${ }^{1}$ in razvijanje socialne kohezije. Kako naj bi to dosegli, eksplicitneje opredeljuje poglavje z naslovom Izobraževanje in urjenje za življenje in delo v družbi, ki temelji na znanju. Po mnenju snovalcev Lizbonske strategije bi morali biti oblikovani izobraževalni programi, ki bi bili prilagojeni različnim skupinam ljudi v različnih obdobjih njihovega življenja: »/.../ mladostniki, brezposelni odrasli in tisti zaposleni, ki tvegajo, da bodo hitre spremembe prehitele njihove sposobnosti« (prav tam, str. 8-9). Vidimo lahko, da ima pri družbenem in gospodarskem razvoju ključno vlogo prav vseživljenjsko izobraževanje. Z vključevanjem različnih ciljnih populacij v programe vseživljenjskega izobraževanja naj bi bilo vsem prebivalcem omogočeno sledenje hitrim družbenim in gospodarskim spremembam, slednje pa naj bi bilo podlaga za vzpostavitev na znanju temelječe družbe in gospodarstva. Da so snovalci Lizbonske strategije pri razvoju Evropske unije stavili prav na vseživljenjsko učenje kot izhodišče za vzpostavitev na znanju temelječe družbe in gospodarstva, je jasno razvidno iz zapisanih ciljev. Ti so bili:

- $\quad$ letno povečanje vlaganj v človeške vire po človeku (per capita);

- $\quad$ število mladih med 18. in 24. letom z nižjo stopnjo izobrazbe, ki niso vključeni v nadaljnje izobraževalne programe, je treba do leta 2010 zmanjšati za polovico;

- $\quad$ šole in izobraževalne ustanove (vse povezane v medmrežje) je treba preoblikovati v večnamenske lokalne izobraževalne centre, ki bodo dostopni vsem;

- $\quad$ uporabiti je treba primerne metode, da bi pritegnili čim širši krog ciljnih skupin;

- $\quad$ med izobraževalnimi in raziskovalnimi ustanovami je treba vzpostaviti povezave za njihovo obojestransko korist;

- $\quad$ evropska podlaga naj opredeli nova osnovna znanja, ki jih je treba pridobiti skozi vseživljenjsko izobraževanje: informacijskotehnološka znanja, tuji jeziki, tehnološka kultura, podjetniške in družbene veščine;

- $\quad$ za osnovna računalniška znanja bi morali uvesti evropsko spričevalo z decentraliziranimi postopki overitve, da bi povečali digitalno pismenost prebivalstva Evropske unije;

- $\quad$ opredeliti (do konca leta 2000) sredstva za pospeševanje mobilnosti študentov, učiteljev in raziskovalcev z najboljšo uporabo obstoječih skupnostnih programov (Socrates, Leonardo, Youth), z odstranitvijo ovir in večjo transparentnostjo pri priznavanju kvalifikacij ter obdobij študija in prakse;

- $\quad$ odstraniti ovire za mobilnost učiteljev do leta 2002 in pritegniti visoko kvalificirane in kvalitetne učitelje (prav tam, str. 9).

Omenjeni cilji kažejo namero po celostnosti razvijanja vseživljenjskega učenja v prostoru Evropske unije. Iz ciljev je razvidno, da vseživljenjsko izobraževanje ne bi bilo usmerjeno le k skrbi za ranljive družbene skupine, ampak bi motiviralo različne ciljne skupine in omogočilo razvijanje ključnih kompetenc ${ }^{2}$ pri celotnem prebivalstvu Evropske unije. Vidimo lahko, da so snovalci Lizbonske strategije želeli čim bolj konkretizirati

1 Eden ključnih ciljev Lizbonske strategije iz leta 2000 je bil zvišanje stopnje zaposlenosti s 56 odstotkov v letu 1999 na 70 odstotkov (Lisbon European Council, 2000, str. 9).

2 Kot ključne kompetence v na znanju temelječi družbi in gospodarstvu Lizbonska strategija navaja na primer digitalno pismenost, podjetništvo in podobno (prav tam, str. 9). 
prednostna področja in cilje na posameznem področju. V našem primeru na področju vseživljenjskega učenja. Slednje pa pušča nekaj nejasnosti pri razumevanju sinergičnih učinkov med različnimi področji, na primer pri razmerju med cilji vseživljenjskega učenja in cilji zvečanja zaposljivosti in socialne integracije pri ranljivih družbenih skupinah. Lizbonska strategija iz leta 2000 tako daje vtis o samoumevnosti sinergije med različnimi gospodarskimi in družbenimi dejavniki.

Kljub temu pa so jasno zapisani cilji na posameznem področju Evropski komisiji omogočali neposredno spremljanje uresničevanja Lizbonske strategije. Podatki za leti 2001 in 2002 so bili za Evropsko unijo spodbudni, saj smo imeli veliko gospodarsko rast (3,5 odstotka) in se je število delovnih mest povečalo. To je nekako ovrglo pomisleke o prej omenjeni pomanjkljivosti Lizbonske strategije, saj je bil indeks gospodarske rasti in zaposlenosti pozitiven. ${ }^{3}$ Ko pa so snovalci evropske politike začeli dobivati občutek o uspešnosti ukrepov Lizbonske strategije, je prišlo leto 2003. Iz poročil v letu 2003 je bilo prvič mogoče zaznati, da je napredek pri doseganju ciljev Lizbonske strategije prepočasen. Kazalniki so se sicer večinoma zviševali, vendar ne s takšnim trendom, kot je bilo načrtovano (Europe 2020 indicators, 2014). ${ }^{4}$

Kljub zaostanku je bila Evropska komisija trdno prepričana, da bo zastavljene cilje do leta 2010 še mogoče doseči, če bodo države članice pospešile uresničevanje. Ker se trendi gospodarske rasti tudi v začetku leta 2004 niso bistveno izboljšali, je Evropska komisija naročila podrobnejše poročilo o izvajanju Lizbonske strategije. Novembra 2004 je bilo predstavljeno tako imenovano Kokovo poročilo, katerega glavna ugotovitev je bila, da je uresničitev ciljev Lizbonske strategije nerealna. Kljub temu je v poročilu zapisano, naj se uresničevanje strategije ne opusti, temveč naj se njeni cilji obnovijo in naj se njihovo doseganje bolj temeljito spremlja (Facing the challenge: The Lisbon strategy for growth and employment, 2004). Posledično je Evropska komisija v prvih dneh februarja 2005 pripravila predlog reforme Lizbonske strategije z naslovom Partnerstvo za rast in delovna mesta: Nov začetek za Lizbonsko strategijo, s katero so želeli racionalizirati procese in povečati učinkovitost izvajanja ukrepov. Bistvene spremembe, ki jih prinaša reforma, so opustitev mejne letnice 2010, zmanjšanje števila ciljev in prenos odgovornosti za morebitni neuspeh na države članice. Tudi na področju izobraževanja je uvedena pomembna sprememba. Še vedno se verjame v moč znanja. »Znanje je kritični dejavnik, s katerim lahko Evropa zagotovi konkurenčnost v svetu, kjer drugi konkurirajo s poceni delovno silo ali s primarnimi surovinami.« (Partnerstvo za rast in delovna mesta: Nov začetek za Lizbonsko strategijo, 2005, str. 20) Vendar pa se znanje ne razume kot samostojna entiteta, kot je bilo v prvotni Lizbonski strategiji, ampak se začne intenzivneje povezovati s področjem inovacij. Skladno s tem lahko v prenovljeni Lizbonski strategiji zasledimo poglavje Znanje in inovacije za rast. V njem se pojavi namera po razvijanju vrhunskega

3 Med letoma 2000 in 2001 ter letom 2002 je indeks BDP v Evropski uniji zrasel za 3,5 oziroma 3,6 odstotka. Indeks brezposelnosti pa se je med letoma 2000 in 2002 znižal za 0,2 odstotka (Europe 2020 indicators, 2014).

4 Indeks BDP se je v letu 2003 zvišal le za 0,9 odstotka (prav tam). 
znanja, ki bo služilo konkurenčni prednosti evropskega gospodarstva. V ospredje so bili postavljeni cilji glede zvečanja vlaganj v raziskave in razvoj, ${ }^{5}$ širjenja univerzitetnega znanja med preostalo evropsko prebivalstvo in razvijanja vrhunskih znanstvenih institucij, kot je denimo Evropski tehnični inštitut (prav tam, str. 25-29). Kot je razvidno iz zapisanega, pa umanjka celostno razvijanje vseživljenjskega izobraževanja, kot smo ga lahko zasledili v prvotni Lizbonski strategiji. Vrzel nekoliko zapolni poglavje Ustvarjajmo nova in boljša delovna mesta oziroma podpoglavje Vlagajmo več v človeški kapital z boljšo izobrazbo, spretnostmi in znanji. V njem se Evropska komisija zavezuje, da bo v letu 2007 spremenila program vseživljenjskega učenja, države članice pa je pozvala $\mathrm{k}$ uvajanju nacionalnih strategij vseživljenjskega učenja (prav tam, str. 32). O tem, kaj naj bi novi program vseboval oziroma na čem naj bi temeljile nacionalne strategije, pa prenovljena Lizbonska strategija ne govori. Ravno ta odprtost na področju vseživljenjskega izobraževanja pušča nacionalnim državam večje možnosti, da oblikujejo lasten koncept vseživljenjskega izobraževanja. Hkrati pa to pomeni, da se ob prejšnjem problemu, tj. umanjkanju prikaza sinergije med izobraževanjem in drugimi segmenti gospodarskega in družbenega razvoja, pojavi še dodatna pomanjkljivost, in sicer razpršen razvoj vseživljenjskega učenja v članicah Evropske unije.

Tako kot prvotna tudi spremenjena Lizbonska strategija ni prinesla želenih rezultatov in zastavljeni cilji do leta 2010 niso bili uresničeni. Ne le, da se večina kazalnikov ni povzpela na želeno raven, ampak se je marsikateri med njimi izrazito poslabšal, predvsem brezposelnost. ${ }^{6}$ Razlog za to je mogoče iskati tudi v prvih (izrazito sunkovitih) vplivih gospodarske recesije. $» V$ zadnjih dveh letih (od leta 2010, op. av.) je zaposlitev izgubilo več milijonov ljudi. Dolgovi so se povečali v taki meri, da se jih več let ne bomo rešili. Vse to je še dodatno obremenilo našo socialno kohezijo. Razkrilo je tudi nekatere temeljne resnice o težavah, v katerih se je znašlo evropsko gospodarstvo. Medtem pa svetovno gospodarstvo napreduje.« (Strategija Evropa 2020: Strategija za pametno, trajnostno in vključujočo rast, 2010, str. 2)

\section{Vloga izobraževanja odraslih v Strategiji Evropa 2020}

Neuspeh prenovljene Lizbonske strategije pa ni omajal upov Evropske komisije pri strateškem spodbujanju gospodarske in socialne rasti ter zmanjševanju brezposelnosti $\mathrm{v}$ Evropski uniji. Na pogorišču Lizbonske strategije je namreč nastal nov strateški program, Strategija Evropa 2020. Snovalci strategije so v povzetku zapisali: »Zasnovati moramo strategijo, ki nam bo pomagala, da bomo ob izhodu iz krize močnejši in bomo sposobni Evropsko unijo preoblikovati v pametno, trajnostno in vključujoče gospodarstvo, ki ga bo odlikovala visoka stopnja zaposlenosti, produktivnosti in socialne kohezije.« (Strategija

5 Cilj prenovljene Lizbonske strategije je bil povečati delež vlaganj v raziskave in razvoj v BDP, in sicer z 2,0 odstotka BDP v letu 2005 na 3,0 odstotka BDP v letu 2010 (Partnerstvo za rast in delovna mesta: Nov začetek za Lizbonsko strategijo, 2005, str. 25).

6 Brezposlenost se je med letoma 2000 in 2010 povzpela s 7,6 kar na 8,3 odstotka (Europe 2020 indicators, 2014). 
Evropa 2020: Strategija za pametno, trajnostno in vključujočo rast, 2010, str. 5) Vidimo lahko, da je tudi v tej strategiji v ospredju razvoja še vedno namera doseganja gospodarske rasti. Vendar se v tem primeru gospodarstvo razume v prenovljeni podobi, saj Strategija Evropa 2020 vsebuje vizijo socialnega tržnega gospodarstva Evrope (prav tam). Predvsem gre za obliko gospodarstva, ki ob ekonomskih učinkih teži tudi k vzpostavitvi družbe blaginje. Sinergija med gospodarskimi in socialnimi elementi koncepta socialnega tržnega gospodarstva v Strategiji Evropa 2020 se izraža v treh temeljnih prvinah:

- pametna rast,

- trajnostna rast in

- $\quad$ vključujoča rast (prav tam, str. 10).

Prva prvina, pametna rast, poudarja na znanju in inovacijah temelječ razvoj gospodarstva. V okviru prvine trajnostna rast so želeli spodbujati bolj konkurenčna in zelena gospodarstva. Zadnja prvina pa poudarja utrjevanje gospodarstva $\mathrm{z}$ visoko stopnjo zaposlenosti, ki krepi socialno in teritorialno kohezijo. Omenjene prvine kažejo sinergijo med izobraževanjem, okoljevarstvom in socialno kohezijo. Če se za trenutek poglobimo $\mathrm{v}$ prvo prvino, pametno rast, vidimo tesno povezavo s prenovljeno Lizbonsko strategijo. Tako kot v prenovljeni Lizbonski strategiji se tudi tukaj koncept znanja v okviru gospodarskega razvoja povezuje $\mathrm{z}$ inovacijami. »Pri pametni rasti je treba $\mathrm{v}$ spodbujanje prihodnje rasti vpreči znanje in inovacije. Zato moramo izboljšati kakovost našega izobraževanja, okrepiti raziskovalne dejavnosti, spodbujati prenos inovacij in znanja po vsej Evropski uniji, v celoti izkoristiti informacijske in komunikacijske tehnologije ter zagotoviti preoblikovanje inovativnih zamisli v nove proizvode in storitve, ki ustvarjajo rast, kakovostna delovna mesta ter pomagajo pri reševanju evropskih in svetovnih družbenih izzivov.« (prav tam, str. 12) Vidimo lahko, da je bistven poudarek pri nadaljnjem razvoju izobraževanja v Evropski uniji na spodbujanju kakovosti in prenosu vrhunskega znanja med članicami Evropske unije. Vendar se Strategija Evropa 2020 ne navezuje zgolj na razvoj vrhunskega inovativnega znanja in njegovo širitev med članicami, ampak tretja prvina odpira možnosti razvoja vseživljenjskega izobraževanja pri celotnem prebivalstvu. Slednje se primarno izraža v dveh kazalnikih. Evropska komisija si je namreč kot dva izmed petih krovnih ciljev do leta 2020 zastavila znižanje stopnje osipa v izobraževanju s 15 na 10 odstotkov in povečanje deleža prebivalstva med 30. in 34. letom starosti, ki je končalo terciarno izobraževanje, z 31 na vsaj 40 odstotkov (prav tam, str. 32). Omenjena kazalnika pomenita vmesno inačico med staro Lizbonsko strategijo, ki je do podrobnosti opredeljevala različne kazalnike vseživljenjskega izobraževanja, in prenovljeno, ki je bolj poudarjala obveznosti različnih institucij kot pa samo vsebino. Strategija Evropa 2020 delno povzema nekatere kazalnike prvotne Lizbonske strategije, od prenovljene pa obvezo Evropske komisije in držav članic za doseganje omenjenih kazalnikov. Zanimivo je, da so kazalniki na področju vseživljenjskega izobraževanja v Strategiji Evropa 2020 tesno povezani zgolj z »mlado« populacijo in formalnim izobraževanjem, umanjkajo pa preostale ciljne skupine in oblike izobraževanja, ki smo jih lahko zasledili pri prvotni Lizbonski strategiji. Razlog za to lahko najdemo v izraziti brezposelnosti mlajše generacije. O tem nas prepričajo tudi vodilne pobude v Strategiji 
Evropa 2020, ki pomenijo instrumente za uresničitev zastavljenih kazalnikov. Evropska komisija je kar dve pobudi od sedmih namenila področju izobraževanja, in sicer:

- »'Mladi in mobilnost' za povečanje uspešnosti izobraževalnih sistemov in olajšanje vstopa mladih na trg dela;

- 'Program za nova znanja in spretnosti in nova delovna mesta' za posodobitev trga dela ter okrepitev vloge ljudi z razvijanjem njihovih znanj in spretnosti v vsem življenjskem obdobju, da bi povečali vključevanje delavcev in bolje uskladili povpraševanje po delovni sili in njeno ponudbo, tudi z mobilnostjo delavcev« (prav tam, str. 5-6).

Tako pobuda »Mladi in mobilnost « kot tudi »Program za nova znanja in spretnosti in nova delovna mesta « jasno kažeta vlogo izobraževanja. Ta je zgolj v službi trga dela, s čimer se ob rob postavljajo vsi drugi nameni izobraževanja.

Primerjalna analiza treh strateških dokumentov Evropske unije, prvotne in prenovljene Lizbonske strategije ter Strategije Evropa 2020, kaže na razmeroma podrobno načrtovanje področja izobraževanja, sploh v prvem dokumentu. Oblikovane so splošne smernice, ki so nadalje razčlenjene $\mathrm{v}$ cilje in ti v kazalnike ter aktivnosti za njihovo uresničitev. V splošnih smernicah Lizbonske strategije smo lahko zaznali izrazito zaupanje v moč izobraževanja pri gospodarskem razvoju. Verjelo se je, da bo kakovostno izobraževanje (in znanje) ključen dejavnik gospodarske rasti Evropske unije. V Strategiji Evropa 2020 pa vera v izobraževanje (in znanje) nekoliko usahne. V okviru prednostnih prvin je izobraževanje (in znanje) le ena od treh prvin, postavljena ob bok okoljevarstvu in socialni koheziji. Čeprav je izobraževanje $\mathrm{v}$ okviru splošnih smernic $\mathrm{v}$ vseh treh strategijah tesno povezano $\mathrm{z}$ gospodarskim razvojem in socialno kohezijo, pa se slednje nekoliko izgubi na ravni ciljev in kazalnikov. Prikaz konkretnega sinergičnega delovanja med tremi entitetami, izobraževanjem, gospodarsko rastjo in socialno kohezijo, je pri ciljih in kazalnikih pomanjkljiv. Kazalniki se namreč izrazito povezujejo s posameznim ozkim področjem. Uspešno izvajanje tako Lizbonske strategije kot Strategije Evropa 2020 pa zahteva celostno obravnavo gospodarskega in družbenega razvoja ter medsebojno usklajenost dejavnikov.

\section{PRIKAZ VKLJUČENOSTI ODRASLIH V IZOBRAŽEVANJE V EVROPSKI UNIJI ${ }^{7}$}

Zaradi lažjega razumevanja dejanskega stanja na področju izobraževanja odraslih v času pred gospodarsko recesijo in na njenem začetku si uvodoma poglejmo temeljne statistične podatke Evropske unije o vključenosti odraslih v izobraževanje v letih 2007 in 2011. Na podlagi raziskave Adult education survey ${ }^{8}$ in drugih ekonomskih podatkov Eurostata

7 Uporabljeni so statistični podatki 28 držav EU, in sicer Avstrije, Belgije, Bolgarije, Cipra, Češke, Danske, Estonije, Finske, Francije, Grčije, Hrvaške, Irske, Italije, Latvije, Litve, Luksemburga, Madžarske, Malte, Nemčije, Nizozemske, Poljske, Portugalske, Romunije, Slovaške, Slovenije, Španije, Švedske in Združenega kraljestva.

8 Raziskava Adult education survey je bila izvedena v okviru Eurostata z namenom ugotoviti, koliko so odrasli vključeni v katerokoli obliko izobraževanja in kako pridobivajo znanje (v letih 2007 in 2011). Sodelovale so vse članice Evropske unije, države EFTA in države kandidatke (Adult education survey - AES, 2012). 
bomo ugotavljali razmerja med izobraževanjem odraslih na eni strani in BDP, brezposelnostjo in revščino na drugi.

Kot je razvidno iz surovih podatkov raziskave Adult education survey, je bila vključenost prebivalcev Evropske unije v formalno ${ }^{9}$ in neformalno izobraževanje v letu 2007 34,8-, v letu 2011 pa 40,3-odstotna. Razlika med vključenostjo v letih 2007 in 2011 je torej znašala 5,2 odstotka v prid leta 2011. Povečanje vključenosti anketirancev v izobraževanje odraslih je posledica povečanega vključevanja v neformalno izobraževanje. ${ }^{10}$ To se je v omenjenih letih povečalo za 5,6 odstotka, vključenost $\mathrm{v}$ formalno izobraževanje pa je za 0,4 odstotka upadla. Pri tem se je treba zavedati, da je bila vključenost $\mathrm{v}$ formalno izobraževanje v letu 2011 za skoraj šestkrat manjša kot vključenost v neformalno izobraževanje (Adult education survey - AES, 2012). Navedeno kaže, da je Evropska unija v gospodarsko recesijo vstopila s povečevanjem neformalnega izobraževanja in upadom formalnega.

Tabela 1: Splošni podatki o izobraževanju, BDP, brezposelnosti in revščini v Evropski uniji

\begin{tabular}{|l|l|l|}
\cline { 2 - 3 } \multicolumn{1}{c|}{} & $\mathbf{2 0 0 7}$ & $\mathbf{2 0 1 1}$ \\
\hline Formalno izobraževanje & $6,6 \%$ & $6,2 \%$ \\
\hline Neformalno izobraževanje & $31,2 \%$ & $36,8 \%$ \\
\hline SKUPAJ - izobraževanje & $34,8 \%$ & $40,3 \%$ \\
\hline BDP & $25.000,00$ EUR & $25.100,00$ EUR \\
\hline Brezposelnost & $7,2 \%$ & $9,6 \%$ \\
\hline Revščina & $24,4 \%$ & $24,3 \%$ \\
\hline
\end{tabular}

Vir: Adult education survey - AES, 2012; Europe 2020 indicators, 2014 11

V želji po ugotavljanju vpliva izobraževanja odraslih na gospodarske dejavnike se za trenutek ustavimo ob podatkih o gospodarskem razvoju Evropske unije in si oglejmo gibanje vrednosti BDP v letih 2007 in 2011. Vidimo lahko, da se je vrednost BDP v letu 2007 gibala okoli 25.000,00 evra. Čez štiri leta pa se je vrednost BDP zvišala za 100,00 evra oziroma za 0,4 odstotka. Naraščanje je mogoče zaznati tudi pri stopnji brezposelnosti. Ta je v Evropski uniji v letu 2007 znašala 7,2 odstotka in v letu 2011 9,6 odstotka. Ugotovimo torej, da se je kljub intenzivni skrbi snovalcev Lizbonske strategije iz let 2000 in 2005

9 Pod pojmom formalno izobraževanje je razumljeno »/.../ namensko, organizirano in v večini primerov institucionalizirano izobraževanje. Odvija se v izobraževalnih institucijah (šole, fakultete), ki sestavljajo izobraževalni sistem neke države. S programi formalnega izobraževanja se pridobi višja stopnja izobrazbe.« (prav tam)

10 Neformalno izobraževanje je namenska in organizirana učna aktivnost, ki se odvija v institucijah ali zunaj njih. Sem spadajo programi za pridobivanje, obnavljanje, razširjanje, posodabljanje ali poglabljanje znanja, s katerimi pa javno veljavne izobrazbe ni mogoče pridobiti (prav tam).

11 Podatki o vključenosti v formalno in neformalno izobraževanje so pridobljeni iz raziskave Adult education survey - AES (2012), podatki o BDP, brezposelnosti in revščini pa iz baz Eurostata (Europe 2020 indicators, 2014). 
stopnja brezposelnosti zvišala kar za 2,4 odstotka. Edini kazalnik, ki je pred vstopom Evropske unije v gospodarsko recesijo upadel, je stopnja revščine. Res je, da je bil upad minimalen, in sicer s 24,4 odstotka v letu 2007 na 24,3 odstotka v letu 2011, pa vendarle je obstajal (Europe 2020 indicators, 2014).

Tabela 2: Stopnja povezanosti med vključenostjo v (formalno in neformalno) izobraževanje ter BDP, brezposelnostjo in revščino v Evropski uniji

\begin{tabular}{|l|l|l|l|l|l|}
\cline { 3 - 6 } \multicolumn{2}{c|}{} & \multicolumn{2}{|l|}{$\begin{array}{l}\text { Vključenost v formalno } \\
\text { izobraževanje }\end{array}$} & $\begin{array}{l}\text { Vključenost v neformal- } \\
\text { no izobraževanje }\end{array}$ \\
\cline { 3 - 6 } \multicolumn{2}{c|}{ BDP } & 2007 & 2011 & 2007 & 2011 \\
\hline \multirow{2}{*}{ Brezposelnost } & 2007 & $0,64^{* *}$ & $0,56^{* *}$ & $0,56^{* *}$ & $0,59^{* *}$ \\
\cline { 2 - 6 } & 2011 & $0,59^{* *}$ & $0,54^{* *}$ & $0,60^{* *}$ & $0,60^{* *}$ \\
\hline \multirow{2}{*}{ Revščina } & 2007 & $-0,15$ & $-0,20$ & $-0,31$ & $-0,24$ \\
\cline { 2 - 6 } & 2011 & $-0,24$ & $-0,21$ & $-0,34$ & $-0,46^{*}$ \\
\cline { 2 - 6 } & 2007 & $-0,44^{*}$ & $-0,47^{*}$ & $-0,50^{*}$ & $-0,64^{* *}$ \\
\hline & 2011 & $-0,46^{*}$ & $-0,49^{* *}$ & $-0,57^{* *}$ & $-0,69^{* *}$ \\
\hline
\end{tabular}

* Izračunane vrednosti so statistično pomembne vsaj pri $\mathrm{p}<0,01$.

* * Izračunane vrednosti so statistično pomembne vsaj pri $p<0,05$.

Vir: lasten ${ }^{12}$

Da vključenost odraslih v izobraževanje ni nepomembna pri spremembi omenjenih kazalnikov, lahko sklepamo na podlagi izračunanega Pearsonovega korelacijskega koeficienta, ki kaže pozitivno povezavo z BDP. Najmočnejša pozitivna povezava se pojavlja med BDP in vključevanjem odraslih v formalno izobraževanje v letu 2007, kjer je vrednost Pearsonovega korelacijskega koeficienta znašala 0,64 . Povezava med vključevanjem odraslih v izobraževanje ter brezposelnostjo in revščino pa se kaže kot zmerna negativna. Pearsonov korelacijski koeficient za brezposelnost in vključenost v izobraževanje kaže šibko negativno povezavo. Najvišjo stopnjo negativne povezanosti lahko zasledimo pri neformalnem izobraževanju in brezposelnosti za leto 2011, ko je znašala -0,46. Slednje kaže, da povečano vključevanje v neformalno izobraževanje minimalno vpliva na znižanje stopnje brezposelnosti. Enako lahko ugotovimo tudi za povezavo med izobraževanjem in revščino. Stopnja revščine je občutno bolj negativno povezana z neformalnim izobraževanjem kot pa s formalnim, kar pomeni, da večje vključevanje prebivalstva v neformalno izobraževanje zmanjšuje revščino. Ob tem je treba poudariti, da se negativna povezanost med revščino in neformalnim izobraževanjem z leti krepi. Izračunani korelacijski koeficienti o povezavi med vključenostjo odraslih v izobraževanje na eni strani ter BDP, brezposelnostjo in 
revščino na drugi kažejo dokaj pomemben vpliv formalnega izobraževanja na dvig BDP in vpliv neformalnega izobraževanja na zmanjšanje brezposelnosti in revščine.

\section{ANALIZA OVIR ODRASLIH PRI VKLJUČEVANJU V IZOBRAŽEVANJE V EVROPSKI UNIJI}

Čeprav se je vključenost odraslih v izobraževanje pokazala kot dejavnik izboljšanja gospodarskih kazalnikov, pa se je smiselno ustaviti ob razlogih za omejeno vključenost odraslih v neformalno in formalno izobraževanje. Podatki o ovirah odraslih pri vključevanju v izobraževanje na podlagi raziskave Adult education survey $(2012)^{13}$ vodijo do naslednjih spoznanj:

- V letih 2007 in 2011 izrazito prevladujejo situacijske ovire oziroma ovire, ki izhajajo iz položaja in načina življenja posameznika. Kot najpogostejše situacijske ovire se pojavljajo družinske obveznosti (45,0 odstotka) in cena izobraževanja, ki obsega 35,0 odstotka vseh navedenih situacijskih ovir. Vidimo lahko, da imajo ekonomski dejavniki pomembno vlogo pri vključevanju v izobraževanje. Glede na odstotek odgovorov situacijskim oviram sledijo institucionalne. Med institucionalnimi ovirami so v ospredju tiste, povezane s časovno neustrezno oblikovanimi urniki (60,0 odstotka), kar nekako sovpada s težavo usklajevanja izobraževanja z družinskimi obveznostmi. Bistveno manj pogosto pa se pojavljajo ovire, povezane s ponudbo izobraževalnih programov (25,0 odstotka) in neizpolnjevanjem vpisnih pogojev na strani anketirancev (15,0 odstotka). Med tremi skupinami ovir so na zadnjem mestu dispozicijske, ki se navezujejo na zdravstvene težave.

- Število v letu 2011 navedenih ovir je za polovico manjše od tistih, ki so bile podane v letu $2007 .{ }^{14}$ Največji osip se je pojavil pri situacijskih ovirah, in sicer za 62,4 odstotka. Omenjeni upad je primarno posledica zmanjšanja navedb ovir, povezanih z družinskimi obveznostmi, kjer je bil osip 20,4-odstoten, in s ceno izobraževalnih programov, kjer je bil osip 18,9-odstoten. Nekoliko manjši upad je bilo mogoče zaznati pri skupini institucionalnih ovir, in sicer za 47,0 odstotka. Na upad je večinoma vplivalo zmanjšanje števila odgovorov, povezanih z neustreznim

13 Pri oblikovanju skupin smo izhajali iz klasifikacije Patricie K. Cross (1981), ki je ovire razdelila v tri skupine, in sicer:

1. $\quad$ situacijske ovire - izhajajo iz človekovega trenutnega položaja in načina življenja. Pri izračunavanju vrednosti smo v to skupino vključili naslednje ovire, ki so bile navedene v raziskavi Adult education survey - AES (2012): stroški izobraževanja, podpora delodajalca in družinske obveznosti;

2. institucionalne ovire - temeljijo na samih izobraževalnih programih in institucijah. Iz raziskave Adult education survey - AES (2012) smo v to skupino ovir vključili podatke o: neustrezni ponudbi izobraževalnih programov, vpisnih pogojih in urniku izvedbe izobraževalnih programov;

3. dispozicijske ovire - so povezane s psihološkimi značilnostmi posameznikov. V okviru prej omenjene raziskave smo $\mathrm{v}$ to skupino uvrstili podatke, ki so povezani z zdravstvenimi težavami posameznika in težavami, ki izvirajo iz starosti anketirancev (prav tam).

Izračunani odstotek za posamezno skupino ovir, ki ga navajamo v besedilu, je nastal kot seštevek vseh navedenih ovir v posamezni skupini.

14 Anketiranci so lahko navedli več razlogov za nevključevanje v izobraževanje. 
urnikom (za 21,3 odstotka) in ponudbo izobraževalnih programov (za 14,9 odstotka). Najmanjši osip je razviden pri dispozicijskih ovirah (za 6,5 odstotka) (Adult education survey - AES, 2012). Nekako pa se ponovi struktura odgovorov, ki smo jo zasledili pri prejšnji točki.

Navedeni podatki o ovirah v Evropski uniji kažejo na pomembnost družbenega položaja posameznika pri vključevanju v izobraževanje. Rezultati razkrivajo, da družbeni položaj pomembno pogojuje način življenja posameznika, tako z vidika urejanja prostega časa kot tudi z vidika finančnih zmožnosti. Da pa situacijske ovire nimajo pomembne vloge le na individualni ravni, ampak tudi na ravni Evropske unije, potrjuje še izračunani Pearsonov korelacijski koeficient. Ta je pokazal, da imajo situacijske ovire šibek negativen vpliv na rast BDP in šibek pozitiven vpliv na revščino. Vrednost Pearsonovega korelacijskega koeficienta se $\mathrm{v}$ obeh primerih giblje med 0,2 in 0,3 .

Tabela 3: Spošni prikaz ovir pri vključevanju odraslih v izobraževanje v Evropski uniij (v odstotkih)

\begin{tabular}{|l|l|l|l|l|l|l|l|}
\cline { 3 - 8 } \multicolumn{2}{c|}{} & \multicolumn{2}{l}{$\begin{array}{l}\text { Situacijske } \\
\text { ovire }\end{array}$} & \multicolumn{2}{l|}{$\begin{array}{l}\text { Institucionalne } \\
\text { ovire }\end{array}$} & \multicolumn{2}{l|}{$\begin{array}{l}\text { Dispozicijske } \\
\text { ovire }\end{array}$} \\
\cline { 3 - 9 } & 2007 & 2011 & 2007 & 2011 & 2007 & 20011 \\
\hline \multirow{2}{*}{ Splošni vpogled } & 91,8 & 42,1 & 75,3 & 28,3 & 15,0 & 8,5 \\
\hline \multirow{3}{*}{ Spol } & Moški & 83,1 & 34,0 & 83,9 & 28,9 & 14,8 & 7,4 \\
\cline { 2 - 9 } & Ženske & 98,8 & 50,2 & 67,5 & 27,7 & 15,2 & 9,5 \\
\hline \multirow{4}{*}{ Starost } & $25-34$ & 97,7 & 50,2 & 76,9 & 32,4 & 4,8 & 2,5 \\
\cline { 2 - 8 } & $35-44$ & 98,3 & 51,7 & 78,5 & 33,0 & 9,7 & 4,3 \\
\cline { 2 - 8 } & $45-54$ & 88,1 & 39,2 & 79,4 & 28,4 & 21,2 & 9,2 \\
\cline { 2 - 8 } & $55-64$ & 67,4 & 25,7 & 60,9 & 18,2 & 32,1 & 18,9 \\
\hline \multirow{5}{*}{ Stopnja izobrazbe } & $0-2$ & 84,9 & 41,9 & 74,0 & 26,7 & 24,9 & 13,0 \\
\cline { 2 - 8 } & $3-4$ & 98,9 & 41,8 & 78,7 & 26,2 & 13,5 & 8,6 \\
\cline { 2 - 8 } & $5-6$ & 83,5 & 43,1 & 69,9 & 33,3 & 6,6 & 3,9 \\
\hline
\end{tabular}

Vir: Adult education survey - AES, 2012

Ravno izrazita poudarjenost situacijskih ovir, ki se navezujejo na različne družbene vloge in položaj anketirancev, pa odpira vprašanje, ali se pri anketirancih iz celotne Evropske unije pojavljajo razlike glede na spol, starost in stopnjo izobrazbe anketirancev.

\section{Spremenljivka spol}

Primerjava odgovorov anketirancev iz Evropske unije v letih 2007 in 20011 glede na spol vodi do enakih ugotovitev, do katerih smo prišli prej, in sicer se kažeta prevlada situacijskih ovir in njihov izrazit upad v letu 2011. Ob navedenem pa je mogoče zaznati nekatere posebnosti, ki so značilne za spremenljivko spol, in sicer: 
- $\quad$ Pri ženskah v Evropski uniji izrazito prevladujejo situacijske ovire. Razlika po spolu pri situacijskih ovirah v obeh letih znaša nekaj več kot 15,0 odstotka v »korist « žensk. Kot najpomembnejše situacijske ovire se pojavljajo družinske obveznosti. Od 50,2 odstotka vseh navedb situacijskih ovir je več kot polovica (27,5 odstotka) povezanih z obremenjenostjo žensk z družino. Po deležu odgovorov žensk se na drugem mestu pojavlja cena izobraževanja (15,0 odstotka v letu 2011). Oddaljenost od kraja bivanja pa je za ženske manj pomembna ovira (7,1 odstotka v letu 2011).

- Iz odgovorov anketirancev v letih 2007 in 2011 je razvidno, da so moški bolj izpostavljeni institucionalnim oviram kot ženske. Vendar je ob tem treba poudariti, da se je razlika med letoma 2007 in 2011 bistveno zmanjšala. V letu 2007 je razlika med spoloma pri tej postavki znašala 16,4 odstotka, v letu 2011 pa je bila le še 1,2 odstotka. Kot glavna institucionalna ovira pri vključitvi moških v izobraževanje je bila navedena neustrezna časovna izvedba izobraževanja. Ta je v letu 2011 dosegla vrednost 19,9 odstotka. Preostali dve institucionalni oviri (ponudba izobraževalnih programov in vpisni pogoji) pa imata pri moških veliko manjši pomen kot prvoomenjena.

- Dispozicijske ovire, ki se navezujejo na zdravstveno stanje in posledice staranja, kažejo manjši upad pri ženskah. Čeprav se pri obeh spolih pomen te ovire zmanjšuje, pa se povečuje razlika med spoloma po letih. Ta je v letu 2007 znašala 0,4 odstotka, v letu 2011 pa kar 2,1 odstotka v »prid« žensk (prav tam).

Iz rezultatov moških in žensk je kot ključna ovira razvidna obremenjenost. Ta se pri ženskah pojavlja v obliki obremenjenosti z družinskimi obveznostmi. Pri moških pa je obremenjenost mogoče zaznati skozi oviro o neustreznem oblikovanju urnika izobraževanja. Poleg obremenjenosti pa je zlasti pri ženskah večji poudarek na finančnih ovirah pri vključevanju v izobraževanje, kar je posledica njihovih nižjih osebnih dohodkov. ${ }^{15}$ Prav tako se ženske ne odločajo za izobraževanje zaradi osebnih razlogov, na primer zdravstvenega stanja.

\section{Spremenljivka starost ${ }^{16}$}

Na podlagi primerjave odgovorov anketirancev glede na njihovo starost lahko zasledimo enake ugotovitve, kot smo jih pri opisu splošnih trendov in spremenljivki spol, in sicer upad števila navedenih ovir v letu 2011 in prevlado situacijskih ovir v letih 2007 in 2011. Spremenljivka starost pa pokaže še dve posebnosti:

- $\quad$ Po 35. letu starosti začne pomen situacijskih in institucionalnih ovir upadati. Kot je razvidno iz podatkov za leto 2011, so prebivalci med 35. in 44. letom v 51,7 odstotka primerov navedli situacijske ovire. V naslednji starostni skupini (45 do 54 let) je delež tovrstnih ovir upadel za 14,5 odstotka, v naslednji skupini (55 do 64 let) pa še za 13,5 odstotka. Slednje je posledica največjega upada ovir, povezanih z družinskimi

15 Osebni dohodek žensk v Evropski uniji je bil v letu 2011 za 16,4 odstotka nižji od osebnega dohodka moških (Europe 2020 indicators, 2014).

16 Anketiranci so bili razdeljeni v štiri starostne skupine. V prvi so bili tisti med 25. in 34. letom, v drugi tisti med 35. in 44. letom, sledi skupina anketirancev med 45. in 54. letom, v zadnji pa so bili anketiranci med 55. in 64. letom starosti (Adult education survey - AES, 2012). 
obveznostmi. Veliko manjši upad je zaslediti pri institucionalnih ovirah. Druga starostna skupina (35 do 44 let) je v 33,0 odstotka primerih navedla institucionalne ovire in presegla tretjo skupino ( 45 do 54 let) za 4,6 odstotka, ta pa zadnjo (55 do 64 let) za 10,2 odstotka. Največji upad v skupini institucionalnih ovir so imele ovire, ki izhajajo iz neustrezno oblikovanega urnika izobraževanja.

- Podatki iz leta 2007 in 2011 kažejo, da število dispozicijskih ovir s starostjo narašča. Tako se je razlika med prvo ( 25 do 34 let) in drugo starostno skupino (35 do 44 let) v letu 2011 povečala za 1,8 odstota. $V$ istem letu se je razlika med naslednjima skupinama ( 35 do 44 let in 45 do 54 let) povečala za 4,9 odstotka. Najbolj pa se je povečala razlika med zadnjima dvema skupinama (45 do 54 let in 55 do 64 let), in sicer za 9,7 odstotka. To kaže, da se s starostjo dispozicijske ovire povečujejo. Omenjena ugotovitev je lahko posledica zavedanja pešanja zdravja in psihofizičnih sposobnosti posameznika (prav tam).

Anketiranci, ki so sodelovali v anketi leta 2011, so poudarili, da se s starostjo zmanjšujejo vse oblike ovir pri vključevanju odraslih v izobraževanja. Situacijske ovire izgubljajo pomen zaradi zmanjševanja družinskih obveznosti. Ovire, izhajajoče iz družinskih obveznosti, dosežejo vrhunec med 35 . in 44. letom starosti, kasneje pa se obremenjenost z družino zmanjšuje. Da se s starostjo tovrstna obremenjenost zmanjšuje, dokazujejo tudi podatki o institucionalnih ovirah. Zmanjševanje pomena ovir, povezanih z neustrezno oblikovanim urnikom, lahko posredno kaže, da so anketiranci po 35. letu starosti manj obremenjeni in se lažje prilagajajo urniku izobraževanja. Razbremenitev družinskih in drugih obveznosti, ki se pojavlja po 35. letu, pa ne vodi v povečano vključevanje odraslih v izobraževanje. Nasprotno, s starostjo namreč izrazito upada vključevanje odraslih tako v formalno kot tudi v neformalno izobraževanje. Razlog za to lahko iščemo v dispozicijskih ovirah, katerih pomen z leti narašča. Raziskava Adult education survey razkriva, da se s starostjo odrasli počutijo manj sposobne za vključevanje v izobraževanje.

\section{Spremenljivka stopnja izobrazbe $e^{17}$}

Vrstni red pomembnosti skupin ovir, ki smo ga navedli pri splošnih ugotovitvah, se potrjuje tudi pri spremenljivki izobrazba. Tako so najpogostejše ovire v vseh skupinah glede na stopnjo izobrazbe situacijske, sledijo institucionalne in dispozicijske. Natančnejši vpogled v strukturo skupin ovir glede na stopnjo izobrazbe pa nas vodi do naslednjih ugotovitev:

- Struktura situacijskih in institucionalnih ovir med letoma 2007 in 2011 se razlikuje. V letu 2007 so prevladovale situacijske (98,9 odstotka) in institucionalne (78,7 odstotka) ovire pri skupini s 3. in 4. stopnjo izobrazbe po ISCED. Pri skupini z najnižjo stopnjo izobrazbe (1.-2.) so omenjene ovire dosegle drugo mesto. Najmanj pa so bile situacijske in institucionalne ovire $\mathrm{v}$ ospredju pri najbolj izobraženem prebivalstvu (4.-5.). V letu 2011 pa je struktura ovir povsem spremenjena. Situacijske in

17 Anketiranci so bili razdeljeni v tri skupine, in sicer glede na klasifikacijo ISCED. V prvi skupini so bili anketiranci z zaključeno 1 . in 2. stopnjo izobrazbe po ISCED, v drugi so bili vsi z zaključeno 3. in 4. stopnjo po ISCED in v zadnji vsi z zaključeno 5. in 6. stopnjo po ISCED (prav tam). 
institucionalne ovire dosegajo najvišje vrednosti pri najbolj izobraženih anketirancih (5.-6.) in najnižje pri skupini s 3. in 4. stopnjo izobrazbe po ISCED. Na slednje vpliva predvsem upad pogostosti ovir, povezanih z družinskimi obveznostmi in neustreznostjo izobraževalne ponudbe v okolju ter neizpolnjevanjem vpisnih pogojev.

- Višanje stopnje izobrazbe vpliva na upad pogostosti dispozicijskih ovir. Anketiranci iz leta 2011, ki so imeli najnižjo stopnjo izobrazbe (1.-2.), so v 13,0 odstotka primerov navedli dispozicijske ovire. V naslednji skupini (3.-4.) je upad tovrstnih ovir dosegel 4,4 odstotka. Skupina anketirancev z najvišjo izobrazbo (5.-6.) pa je tem oviram namenila le 3,9 odstotka navedb (prav tam). Prikazani podatki so izraz tega, da se bolj izobraženo prebivalstvo počuti bolj samozavestno in je intelektualno bolj aktivno.

Podatki o stopnji izobrazbe vodijo do ugotovitve, da je najbolj izobraženo prebivalstvo najmanj izpostavljeno različnim skupinam ovir. Izjema so institucionalne ovire, v okviru katerih so v letu 2011 prevladovale ovire, povezane z neustrezno oblikovanim urnikom. Slednje je v tesni povezavi z ovirami, izhajajočimi iz družinskih obveznosti, kar kaže na obremenjenost najbolj izobraženega prebivalstva s službenimi in družinskimi nalogami.

\section{NAMESTO SKLEPA}

Uvodoma smo si postavili vprašanje o razumevanju vpliva izobraževanja odraslih na gospodarske kazalnike v Evropski uniji pred gospodarsko krizo in na samem začetku krize. Da se je Evropska komisija zavedala pomena izobraževanja (odraslih) pri razvoju Evropske unije, se jasno kaže v ključnih strateških dokumentih. Tako prvotna kot tudi prenovljena Lizbonska strategija je stavila na vzpostavitev družbe in gospodarstva, ki bosta temeljila na znanju. Znanje naj bi zagotovilo dvig BDP, zmanjšanje brezposelnosti in povečanje socialne kohezivnosti. Vendar je sama implementacija Lizbonske strategije pokazala, da vzpostavitev omenjenega koncepta v praksi vendarle ni tako enostavna. Tako se niso uresničili kazalniki iz nobene od različic Lizbonske strategije. Vendar s tem Evropska komisija ni končala strateškega načrtovanja razvoja Evropske unije in poudarjanja vloge znanja. Za obdobje 2010 in 2020 je bil sprejet dokument Strategija Evropa 2020, ki pa nič več tako izrazito ne vztraja pri izobraževanju, ampak ga postavlja ob bok inovacijam, okoljevarstvu in zaposlovanju. Čeprav so posamezna vsebinska področja jasno oblikovana, pa se tudi v novem strateškem dokumentu ponavlja nejasna sinergija med omenjenimi področji, sploh na ravni kazalnikov in aktivnosti. Kazalniki in aktivnosti v Stategiji Evropa 2020 kažejo na izrazito fragmentarno urejanje »problematičnih« področij, kar se vidi tudi pri izobraževanju odraslih. Slednje je primarno razumljeno v okvirih trga dela in usposabljanja mladih za potrebe prve zaposlitve.

V drugem delu prispevka smo se osredotočili na same kazalnike Evropske unije na področju gospodarskega razvoja in izobraževanja v letu 2007 in 2011 . Rezultati raziskave Adult education survey so pokazali, da so se odrasli v letu $2011 \mathrm{v}$ povprečju več izobraževali kot v letu 2007. Vendar je pri tem treba omeniti, da se je izrazito povečala vključenost v neformalno izobraževanje, nekoliko pa zmanjšala vključenost v formalno. Izračun 
korelacijskih koeficientov o povezavi med izobraževanjem na eni strani ter gibanjem BDP, brezposelnosti in revščine na drugi nas je pripeljal do ugotovitve o pozitivnem vplivu izobraževanja na dvig BDP in negativnem vplivu na brezposelnost in revščino. Slednje govori v prid dejstvu, ki smo ga lahko zasledili v omenjenih strateških dokumentih Evropske komisije, in sicer, da ima vključevanje prebivalstva $\mathrm{v}$ izobraževanje pozitivne gospodarske in družbene učinke. Je pa res, da večinoma izobraževanje nima (v kratkem obdobju) tako izrazitega vpliva, kot ga je predvidevala Evropska komisija. Na primeru analize ovir, s katerimi se srečujejo odrasli pri vključevanju v izobraževanje, se je jasno pokazala potreba po sinergičnem delovanju in povezovanju razvoja izobraževanja odraslih z drugimi družbenimi dejavniki. Ravno izrazito izstopanje situacijskih ovir odpira vprašanje o sinergičnem snovanju razvoja izobraževanja z družinsko in zaposlitveno politiko. Slednjega pa skozi aktivnosti in kazalnike tako Lizbonske strategije kot tudi Strategije Evropa 2020 ni bilo mogoče zaznati.

\section{LITERATURA}

Adult education survey - AES (2012). Pridobljeno s http://epp.eurostat.ec.europa.eu/portal/page/portal/ microdata/adult_education_survey.

Cross, K. P. (1981). Adults as learners: increasing participation and facilitating learning. San Francisco: Jossey-Bass Publishers.

Education at a glance: OECD indicators (2009). Paris: Organisation for economic Co-operation and development.

Europe 2020 indicators (2014). Pridobljeno s http://epp.eurostat.ec.europa.eu/portal/page/portal/ europe_2020_indicators/headline_indicators.

Facing the challenge: The Lisbon strategy for growth and employment (2004). Luxembourg: Office for Official Publications of the European Communities. Pridobljeno s http://epp.eurostat.ec.europa.eu/ portal/page/portal/statistics/search_database.

Lisbon European Council (2000). Brussels: European Parliament. Pridobljeno s http://www.europarl. europa.eu/summits/lis1_en.htm.

Partnerstvo za rast in delovna mesta: Nov začetek za Lizbonsko strategijo (2005). Luksemburg: Urad za uradne publikacije Evropskih skupnosti.

Strategija Evropa 2020: Strategija za pametno, trajnostno in vključujočo rast (2010). Luksemburg: Urad za uradne publikacije Evropskih skupnosti. 